\title{
Evaluation of the cytotoxic effects of Cyperus longus extract, fractions and its essential oil on the PC3 and MCF7 cancer cell lines
}

\author{
TOKTAM MEMARIANI $^{1}$, TOKTAM HOSSEINI ${ }^{2}$, HOSSEIN KAMALI $^{3}$, \\ AMENEH MOHAMMADI ${ }^{4}$, MARYAM GHORBANI $^{5}$, ABDOREZA SHAKERI $^{6}$, \\ DEMETRIOS A. SPANDIDOS ${ }^{7}$, ARISTIDIS M. TSATSAKIS ${ }^{8}$ and SHABNAM SHAHSAVAND $^{4,9}$
}

\begin{abstract}
${ }^{1}$ Central Research Laboratory, North Khorasan University of Medical Sciences; ${ }^{2}$ Department of General Health, School of Health Sciences, North Khorasan University of Medical Sciences, Bojnurd; ${ }^{3}$ Targeted Drug Delivery Research Center, School of Pharmacy, Mashhad University of Medical Sciences, Mashhad; ${ }^{4}$ Research Center of Natural Products and Medicinal Plants, North Khorasan University of Medical Sciences, Bojnurd; ${ }^{5}$ Department of Pharmacology and Toxicology, School of Pharmacy, Baqiyatallah University of Medical Sciences, Tehran; ${ }^{6}$ Department of Pediatrics, School of Medicine, North Khorasan University of Medical Sciences, Bojnurd, Iran; ${ }^{7}$ Laboratory of Clinical Virology and ${ }^{8}$ Department of Forensic Sciences and Toxicology,

School of Medicine, University of Crete, Heraklion, Greece; ${ }^{9}$ Department of Physiology and Pharmacology,

School of Medicine, North Khorasan University of Medical Sciences, Bojnurd, Iran
\end{abstract}

Received November 18, 2015; Accepted December 23, 2015

DOI: $10.3892 / \mathrm{ol} .2015 .4050$

\begin{abstract}
Cyperus longus is one of the Iranian endemic species. However, to date, and to the best of our knowledge, there are no availale academic reports on the cytotoxicity of this plant. Thus, this study was carried out to examine the in vitro anti-proliferative and anti-apoptotic effects of Cyperus longus extract, fractions and essential oil (EO) on MCF7 and PC3 cell lines. The chemical constituents of EO were identified using gas chromatography (GC)-mass spectrometry (MS) analysis. The cells were cultured in RPMI-1640 medium and incubated with various concentrations of the plant extract and fractions. Cell viability was quantified by MTT assay following 24, 48 and $72 \mathrm{~h}$ of exposure to $(12.5-200 \mu \mathrm{g} / \mathrm{ml})$ of the methanol extract, the dichloromethane $\left(\mathrm{CH}_{2} \mathrm{Cl}_{2}\right)$, ethyl acetate (EtOAc) and water fractions, as well as the $\mathrm{EO}$ of the plant. The percentage of apoptotic cells was determined using propidium iodide staining of DNA fragments by flow cytometry (sub-G1 peak). The most effective fraction in the MCF7 cell line was the $\mathrm{CH}_{2} \mathrm{Cl}_{2}$ fraction ( $\mathrm{IC}_{50}$ after $48 \mathrm{~h}, 25.34 \pm 2.01$ ). The EtOAc fraction $\left(\mathrm{IC}_{50}\right.$ after $\left.48 \mathrm{~h}, 35.2 \pm 2.69\right)$ and the methanol extract $\left(\mathrm{IC}_{50}\right.$ after $\left.48 \mathrm{~h}, 64.64 \pm 1.64\right)$ were also
\end{abstract}

Correspondence to: Dr Shabnam Shahsavand, Department of Physiology and Pharmacology, School of Medicine, North Khorasan University of Medical Sciences, P.O. Box 94176-94735, Bojnurd, Iran E-mail: shabnamshahsavand@gmail.com

Key words: apoptosis, Cyperus longus, cytotoxicity, MTT, cancer, viridiflorol, longiverbenone found to be effective. The $\mathrm{IC}_{50}$ values obtained for the PC3 cell line were $37.97 \pm 3.87,51.57 \pm 3.87$ and $70.33 \pm 2.36$ for the $\mathrm{CH}_{2} \mathrm{Cl}_{2}$ fraction, the EtOAc fraction and the methanol extract, respectively. Based on these data and due to the partial polarity of the most effective fraction (the $\mathrm{CH}_{2} \mathrm{Cl}_{2}$ fraction), we also examined the cytotoxicity of the plant $\mathrm{EO}$. The $\mathrm{IC}_{50}$ values after $48 \mathrm{~h}$ were $22.25 \pm 4.25$ and $12.55 \pm 3.65$ in the PC 3 and MCF7 cell lines, respectively. DNA fragmentation assay also confirmed these data. Performing GC-MS analysis for the plant EO revealed that $\beta$-himachalene $(10.81 \%), \alpha$-caryophyllene oxide $(7.6 \%)$, irisone $(4.78 \%), \beta$-caryophyllene oxide $(4.36 \%)$, humulene oxide (12\%), viridiflorol (4.73\%), aristolone (6.39\%) and longiverbenone (6.04\%) were the main constituents. Our results demonstrated that two of the constituents of Cyperus longus, viridiflorol and longiverbenone, should be investigated further as possible promising chemotherapeutic agents in cancer treatment.

\section{Introduction}

Plants have long been used in the treatment of a variety of diseases, including cancer. Several anticancer drugs, such as vincristine, etoposide, vinblastine, irinotecan, paclitaxel (taxol) and topotecan are botanical secondary metabolites or semi-synthetic derivatives (1). Apigenin (2), deguelin (3), kaempferol (4), luteolin (5-7), quercetin (8-11), rutin (12-16), tricin (17), xanthomicrol (18), $\alpha$-copaene (19), $\alpha$-humulene $(20,21)$ and $\beta$-himachalene (22) are some botanical ingedients that have been investigated as possible future remedies for use in chemotherapy. Xanthomicrol and calycopterin have also been shown to exert potent inhibitory effects on microvessel outgrowth and that these anti-angiogenic effects enhance the antitumor activity (18). 
Cyperaceae is a large family of plants known as sedges, with 5,500 species described. They are known as traditional medicines; however they have to be more extensively investigated (23). From Cyperaceae, Cyperus kyllingia has been shown to exert cytotoxic effects on NCI-H187 cells (small cell lung cancer cells) (24) and the main chemical constituents of its effective essential oil (EO) are $\alpha$-humulene, an agent with reported anticancer activity (21) and caryophyllene, that facilitates the penetration of $\alpha$-humulene through the cell membrane and potentiates its anticancer activity (25). Furthermore, Cyperus rotundus has been shown to exert cytotoxic effects on SH-SY5Y human neuroblastoma (26) and K562 erythroleukemia cells (27). However, the total oligomeric flavonoids (TOFs) and ethyl acetate (EtOAc) extract of Cyperus rotundus have exhibited weak anticancer effects on L1210 cells ( $\mathrm{IC}_{50}=240$ and $200 \mu \mathrm{g} / \mathrm{ml}$, respectively) (28).

Cyperus longus L. (Cyperaceae) is an Egyptian traditional plant that is used as a diuretic and tonic herbal medicine. It is widely distributed in the Middle East (29). Several flavonoids $(30)$, terpenoids $(31,32)$ and stilbenes $(33)$ have been isolated from this plant. However, to date, and to the best of our knowledge, there is no available scientific report of the anticancer acivity of Cyperus longus. al-Samarqandi (13-14th century, Iran) and al-Kindi (10th century, Iraq) had been prescribing this plant as a traditional remedy in cases that were suspected to be cancer (34). In 2012, Ait-Ouazzou et al (31) evaluated the chemical composition of Cyperus longus EO. $\alpha$-humulene (16.7\%), $\gamma$-himachalene (10.1) and $\beta$-himachalene (46.6\%) were found to be the main constituents and they all exhibited anticancer activity (31). Flavonoids as botanical ingredients exhibit a wide range of biological effects, such as anticancer activities $(5,12,35)$. Luteolin and tricin are two flavonoids that are isolated from Cyperus longus (30), and they have been reported to possess cytotoxic activity against cancer cell lines $(6,7,17)$. In 2010, Morikawa et al determined the antioxidant activity of resveratrol (a polyphenol or stilbene) and its oligomer, pallidol, in the methanol extract of Cyperus longus (29). These two stilbenes have been shown to exert anticancer effects on cancer cell lines (36). The resveratrol analogue, DMU-212, was shown to inhibit HepG2 and MCF7 cell proliferation by inducing apoptosis and $\mathrm{G} 2 / \mathrm{M}$ arrest through the upregulation of p53 and Bax/Bcl-xL (37). Pallidol has also been shown to exert significant cytotoxic effects against A549 cells (38).

Based on these data, it seems Cyperus longus possesses significant anticancer activity. An important step in determining the chemical constituents of plants is preliminary phytochemical screening. Thus, in this study, we examined the plant extract, fraction by fraction, for its anticancer activity against two cancer cell lines (MCF7 and PC3) and one transformed non-malignant (normal) cell line (L929). After comparing the fractions, we evaluated the major constituents that may be responsible for the cytotoxic effects. Finally, we introduced these suspected ingredients as possible candidates for further investigation in cancer chemotherapy.

\section{Materials and methods}

Reagents. Propidium iodide (PI), dimethylsulphoxide (DMSO), 3-(4,5-dimethylthiazol-2-yl)-2,5-diphenyltetrazolium bromide (MTT) solution, Triton X-100, paclitaxel and other chemicals of analytical grade were purchased from Sigma (St. Louis, MO, USA), Roswell Park Memorial Institute (RPMI)-1640 medium, fetal bovine serum (FBS), antibiotic solution (penicillin 1,000 IU and streptomycin $10 \mathrm{mg} / \mathrm{ml}$ ) were obtained from Gibco (Grand Island, NY, USA).

Collection of plant material. The total plant was collected from Bojnurd and the surrounding areas in North Khorasan, Iran. The plant was identified by researchers from the Research Center of Natural Product Health, North Khorasan University of Medical Sciences, Bojnurd, Iran. The herbarium code was MP96.

Preparation of extracts. The plant was shade-dried and then ground to a powder using a mortar and pestle. The powder was stored in air-tight sealed bottles. The shade-dried $(100 \mathrm{~g})$ powder of the plant was suspended in absolute methanol $(350 \mathrm{ml})$ at room temperature for 7 days. The whole extract was filtered through a paper filter and the solvent was evaporated under a vacuum at $45^{\circ} \mathrm{C}$, to yield $12.6 \mathrm{~g}$ crude (yield $12.6 \%$ ) extract. Fractionation was carried out as described in the study by Parsaee et al (39). Briefly, the solution was successively partitioned with dichloromethane $\left(\mathrm{CH}_{2} \mathrm{Cl}_{2}\right)$, EtOAc and finally, water. The $\mathrm{CH}_{2} \mathrm{Cl}_{2}$, EtOAc and water fractions were evaporated under a vacuum to yield residues of 3.31,4.22 and $4.35 \mathrm{~g}$, respectively. The extracts were stored at $4^{\circ} \mathrm{C}$ until analysis. A partitioning scheme of the methanol extract is presented in Fig. 1.

Extraction of EO. The EO was extracted according to a previously described method (40) with minor modifications. Briefly, the dried whole plant (480 g) was ground and hydro-distilled for $5 \mathrm{~h}$ using a Clevenger apparatus (ISO glass ${ }^{\circledR}$; Sina Shisheh Co., Tehran, Iran). The upper oily layer of the extract was separated and dried with anhydrous sodium sulfate. The sample obtained was stored in tightly closed dark vials at $-20^{\circ} \mathrm{C}$ until analysis. The EO was a light yellow transparent liquid with a $0.45 \%(\mathrm{v} / \mathrm{w})$ yield.

Cell lines and culture. The human prostate cancer cell line (PC3), human breast cancer cell line (MCF-7) and mouse fibroblast cell line (L929; as a non-malignant cell line) were obtained from Pasteur Institute (Tehran, Iran). The cells were maintained at $37^{\circ} \mathrm{C}$ in a humidified atmosphere $95 \%$ containing $5 \% \mathrm{CO}_{2}$. All cell lines were cultured in RPMI-1640 with $10 \% \mathrm{v} / \mathrm{v}$ FBS, $100 \mathrm{U} / \mathrm{ml}$ penicillin and $100 \mathrm{mg} / \mathrm{ml}$ streptomycin, as previously described (41).

MTT assay. The evaluation of cytotoxicity was peformed using MTT assay, as previously described $(42,43)$. The cells were plated in a 96-well culture plate with various concentrations $(12.5-200 \mu \mathrm{g} / \mathrm{ml})$ of the methanol extract and fractions. The cultured plates were incubated for 24,48 and $72 \mathrm{~h}$ at $37^{\circ} \mathrm{C}$ and $5 \% \mathrm{CO}_{2}$. Following incubation, $20 \mu \mathrm{l}$ MTT solution in phosphate-buffered saline (PBS) were added to each well at a final concentration of $0.5 \mathrm{mg} / \mathrm{ml}$ followed by further incubation for $3 \mathrm{~h}$ at $37^{\circ} \mathrm{C}$. The medium was then removed, and $100 \mathrm{ml}$ DMSO were added to each well for solubilizing the formazan. The absorbance was measured at $490 \mathrm{~nm}(630 \mathrm{~nm}$ as a reference) using an ELISA reader (Start Fax 2100; Awareness Technology Inc., Fisher Bioblock Scientific, Tournai, Belgium). Three independent experiments were carried out and 8 replicates were taken for each experiment. The concentration 


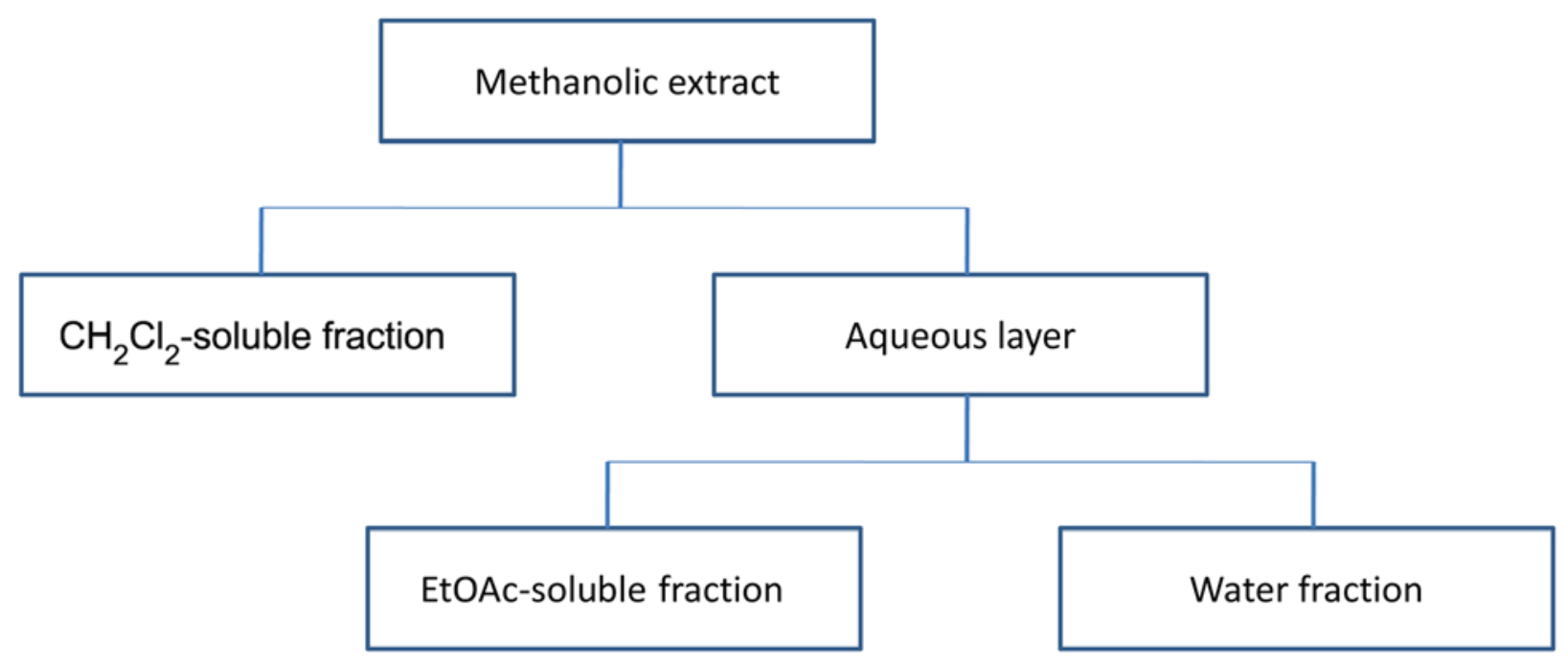

Figure 1. Partioning scheme of the methanolic extract. $\mathrm{CH}_{2} \mathrm{Cl}_{2}$, dichloromethane; EtOAc, ethyl acetate.

of the methanol extract and fractions which resulted in a $50 \%$ reduction of cell viability, the half maximal inhibitory concentration $\left(\mathrm{IC}_{50}\right.$ value), was calculated using the following formula: $\%$ inhibition $=($ control abs - sample abs $) /($ control abs) x 100. Paclitaxel was used as a positive control at the concentration of $0.2-50 \mu \mathrm{g} / \mathrm{ml}$.

DNA fragmentation assay. For in vitro DNA fragmentation assay, all cell lines $\left(1 \times 10^{5} \mathrm{cells} / \mathrm{ml}\right)$ were incubated in a 12-well plate with $75 \mu \mathrm{g} / \mathrm{ml}$ of methanol extract and the fractions, for $48 \mathrm{~h}$ at $37^{\circ} \mathrm{C}$ and $5 \% \mathrm{CO}_{2}$. The optimal concentration $(75 \mu \mathrm{g} / \mathrm{ml})$ and time point $(48 \mathrm{~h})$ for this method were selected based on the data resulting from MTT assay. Paclitaxel was used as a positive control at the concentration of $0.35 \mu \mathrm{M}$. Floating and adherent cells were harvested and incubated for $5 \mathrm{~h}$ at $4^{\circ} \mathrm{C}$ in the dark with $750 \mathrm{ml}$ of a hypotonic buffer $(50 \mu \mathrm{g} / \mathrm{ml} \mathrm{PI}$ in $0.1 \%$ sodium citrate plus $0.1 \%$ Triton $\mathrm{X}-100 \mathrm{PBS}$ ) prior to flow cytometric analysis using a FACScan flow cytometer (BD Biosciences, Franklin Lakes, NJ, USA). The sub-G1 peak was analyzed by FACScan using CellQuest software (BD Biosciences), as previously described (42).

Gas chromatography-mass spectrometry (GC-MS) analysis. For the EO of the plant, GC-MS analysis was carried out using a Shimadzu-QP2010SE chromatograph mass spectrometer (qp 2010 ultra; serial no. 01139; Shimadzu, Kyoto, Japan) operating at $70 \mathrm{eV}$ ionization energy, equipped with a HP-5 capillary column (serial no. 1107908; Restek Corp., Bellefonte, PA, USA; phenylmethyl siloxane, $30 \mathrm{~m} \mathrm{x} 0.25 \mathrm{~mm}$; with $0.25 \mu \mathrm{m}$ film thickness) with helium as the carrier gas, flow rate $1 \mathrm{ml} / \mathrm{min}$ and a split ratio of 1:20. The acquisition mass range was $35-300$ and the scan time was $0.5 \mathrm{sec} / \mathrm{scan}$. The retention indices were determined using the retention times of n-alkanes as a standard that had been injected after the sample under the same chromatographic conditions. The compounds were identified by comparison of the retention indices (RRI, HP-5) as well as by comparison of their mass spectra with the Wiley and Mass Finder 3 libraries or with the published mass spectra (44).
Statistical analysis. Data are expressed as the means \pm standard deviation of at least 3 independent determinations in 8 replicates for each experimental point. Statistical tests were performed using one-way ANOVA followed by the Tukey-Kramer post hoc test for multiple comparisons. A value of $\mathrm{P}<0.05$ was considered to indicate a statistically significant difference.

\section{Results}

Effects of the extract, different fractions and EO of Cyperus longus on cell viability. The effects of Cyperus longus were examined in a time-response experiment after 24,48 and $72 \mathrm{~h}$, at concentrations of $12.5-200 \mu \mathrm{g} / \mathrm{ml}$. The viability of the MCF7 and PC3 cells was significantly inhibited by the methanol extract, the $\mathrm{CH}_{2} \mathrm{Cl}_{2}$ and EtOAc fractions and the $\mathrm{EO}$ of the plant in a time-dependent manner at 24, 48 and $72 \mathrm{~h}$, as shown in Table I. There was no significant activity in the L929 normal cells ( $\mathrm{IC}_{50}>100 \mu \mathrm{g} / \mathrm{ml}$ ) (data not shown). The critical time point for the cytotoxic activity was $48 \mathrm{~h}$ following exposure; this indicates that there was a delay in reaching the maximum effect in both cell lines for all the samples. In the MCF7 cell line, the most effective fraction was the $\mathrm{CH}_{2} \mathrm{Cl}_{2}$ fraction $\left(\mathrm{IC}_{50}\right.$ after $\left.48 \mathrm{~h}, 25.34 \pm 2.01\right)$ followed by the EtOAc fraction ( $\mathrm{IC}_{50}$ after $48 \mathrm{~h}, 35.2 \pm 2.69$ ); these fractions were both more effective than the primary methanol extract $\left(\mathrm{IC}_{50}\right.$ after $48 \mathrm{~h}, 64.64 \pm 1.64)$. In the PC3 cells, the $\mathrm{IC}_{50}$ values were $37.97 \pm 3.87,51.57 \pm 3.87$ and $70.33 \pm 2.36$, for the $\mathrm{CH}_{2} \mathrm{Cl}_{2}$ fraction, EtOAc fraction and methanol extract, respectively. The water (aqueous) fraction did not exhibit an acceptable cytotoxic activity in any of the two cancer cell lines $\left(\mathrm{IC}_{50}\right.$ values $>100 \mu \mathrm{g} / \mathrm{ml})$.

Based on these data and on the polarity of the most effective fraction $\left(\mathrm{CH}_{2} \mathrm{Cl}_{2}\right)$, we decided to determine the cytotoxic activity of the plant EO. Our results revealed that the EO was more effective than even the $\mathrm{CH}_{2} \mathrm{Cl}_{2}$ fraction in both cell lines $\left(\mathrm{IC}_{50}\right.$ after $48 \mathrm{~h}, 22.25 \pm 4.25$ in the PC 3 cells and $12.55 \pm 3.65$ in the MCF7 cell). As shown in Table I, the EO, and the EtOAc and $\mathrm{CH}_{2} \mathrm{Cl}_{2}$ fractions were significantly more effective at exerting 
Table I. Half maximal inhibitory concentrations $\left(\mathrm{IC}_{50}\right)$ of the extract, fractions and essential oil of Cyperus longus in the MCF7 and PC3 cell lines following 24,48 and $72 \mathrm{~h}$ of exposure.

\begin{tabular}{|c|c|c|c|c|c|c|}
\hline \multirow[b]{2}{*}{ Treatment agent } & \multicolumn{3}{|c|}{$\mathrm{IC}_{50}$ in $\mathrm{MCF} 7$ cells } & \multicolumn{3}{|c|}{$\mathrm{IC}_{50}$ in $\mathrm{PC} 3$ cells } \\
\hline & $24 \mathrm{~h}$ & $48 \mathrm{~h}$ & $72 \mathrm{~h}$ & $24 \mathrm{~h}$ & $48 \mathrm{~h}$ & $72 \mathrm{~h}$ \\
\hline Aqueous fraction & $>100$ & $>100$ & $>100$ & $>100$ & $>100$ & $>100$ \\
\hline Methanolic extract & $>100$ & $64.64 \pm 1.64$ & $93.47 \pm 5.11$ & $>100$ & $70.33 \pm 2.36$ & $95.82 \pm 1.96$ \\
\hline $\mathrm{CH}_{2} \mathrm{Cl}_{2}$ fraction & $22.17 \pm 2.33^{\mathrm{a}}$ & $25.34 \pm 2.01^{\mathrm{b}}$ & $43.15 \pm 3.02^{\mathrm{a}}$ & $58.01 \pm 6.39$ & $37.97 \pm 3.87$ & $72.39 \pm 6.84$ \\
\hline Ethyl acetate fraction & $42.38 \pm 2.54^{\mathrm{b}}$ & $35.2 \pm 2.69^{\mathrm{a}}$ & $55.38 \pm 4.25^{\mathrm{a}}$ & $72.37 \pm 3.69$ & $51.57 \pm 3.89$ & $73.22 \pm 3.64$ \\
\hline Essential oil & $21.17 \pm 2.01^{\mathrm{b}}$ & $12.55 \pm 3.65^{\mathrm{c}, \mathrm{d}}$ & $31.35 \pm 3.69$ & $43.65 \pm 4.12$ & $22.25 \pm 4.25^{\mathrm{e}}$ & $39.91 \pm 3.21$ \\
\hline $\begin{array}{l}\text { Paclitaxel } \\
\text { (positive control) }\end{array}$ & $6.34 \pm 0.81^{\mathrm{a}}$ & $3.45 \pm 0.39^{\mathrm{a}}$ & $6.75 \pm 0.57^{\mathrm{a}}$ & $0.10 \pm 0.02$ & $0.09 \pm 0.03$ & $0.08 \pm 0.03$ \\
\hline
\end{tabular}

The $\mathrm{IC}_{50}$ values were quantified by MTT assay. The data are presented as the means \pm standard deviation $(\mathrm{n}=5)$. Letters (d-f) are an indicator of statistical differences obtained separately between essential oil and palitaxel $\left({ }^{\mathrm{d}} \mathrm{P}<0.05\right.$ and $\left.{ }^{\mathrm{e}} \mathrm{P}<0.001\right)$ after $48 \mathrm{~h}$ of exposure (most effective time point) and letters (a-c) are an indicator of statistical differences obtained separately for the MCF7 cell line compared to the PC 3 cell line at each time point ( ${ }^{\mathrm{C}} \mathrm{P}<0.05,{ }^{\mathrm{P}} \mathrm{P}<0.01$ and $\left.{ }^{\mathrm{a}} \mathrm{P}<0.001\right) . \mathrm{CH}_{2} \mathrm{Cl}_{2}$, dichloromethane.

Table II. Effects of the extract, fractions and essential oil of Cyperus longus on the sub-G1 cell population (apoptosis, \%) in the MCF7 and PC3 cell lines following $48 \mathrm{~h}$ of exposure.

Percentage of apoptotic cells

\begin{tabular}{lrrr}
\cline { 2 - 3 } Treatment agent & L929 cells & MCF7 cells & PC3 cells \\
\hline Control & $2.72 \pm 3.19$ & $3.2 \pm 1.59$ & $3.65 \pm 1.61$ \\
Aqueous fraction, $75 \mu \mathrm{g} / \mathrm{ml}$ & $6.25 \pm 3.21$ & $7.59 \pm 1.54$ & $9.87 \pm 1.31$ \\
Methanolic extract, $75 \mu \mathrm{g} / \mathrm{ml}$ & $20.85 \pm 3.07$ & $51.72 \pm 7.2^{\mathrm{a}}$ & $25.07 \pm 4.21$ \\
$\mathrm{CH}_{2} \mathrm{Cl}_{2}$ fraction, $75 \mu \mathrm{g} / \mathrm{ml}$ & $22.69 \pm 4.35$ & $78.35 \pm 5.65^{\mathrm{b}}$ & $60.39 \pm 5.32$ \\
Ethyl acetate fraction, $75 \mu \mathrm{g} / \mathrm{ml}$ & $27.35 \pm 6.65$ & $68.89 \pm 3.34^{\mathrm{b}}$ & $50.89 \pm 6.87$ \\
Essential oil, $75 \mu \mathrm{g} / \mathrm{ml}$ & $29.22 \pm 3.68$ & $78.23 \pm 2.86^{\mathrm{c}}$ & $65.35 \pm 2.35$ \\
Paclitaxel (positive control), $0.35 \mu \mathrm{M}$ & $90.15 \pm 2.33$ & $89.1 \pm 5.79$ & $98.66 \pm 3.43^{\mathrm{d}}$
\end{tabular}

The sub-G1 population (apoptosis \%) was quantified by in vitro DNA fragmentation assay using a FACScan flow cytometer. The data are presented as the means \pm standard deviation $(n=3)$. The letter $(d)$ is an indicator of statistical differences obtained separately between essential oil and palitaxel $\left({ }^{\mathrm{d}} \mathrm{P}<0.001\right)$ and letters $(\mathrm{a}-\mathrm{c})$ are an indicator of statistical differences obtained separately for the MCF7 cell line compared to the PC3 cell line ( ${ }^{\mathrm{C}} \mathrm{P}<0.05,{ }^{\mathrm{b}} \mathrm{P}<0.01$ and $\left.{ }^{\mathrm{a}} \mathrm{P}<0.001\right) . \mathrm{CH}_{2} \mathrm{Cl}_{2}$, dichloromethane.

cytotoxic effects on the MCF7 cells compared to the PC3 cells $(\mathrm{p}<0.05, \mathrm{p}<0.001$ and $\mathrm{p}<0.01$, respectively). There was a significant difference in the $\mathrm{IC}_{50}$ values between the plant $\mathrm{EO}$ and paclitaxel in the MCF7 cells (12.55 \pm 3.65 and $3.45 \pm 0.39$, respectively; $\mathrm{p}<0.05)$; however, in the PC3 cells, this difference was even more significant $(22.25 \pm 4.25$ and $0.09 \pm 0.03$, respectively; $\mathrm{p}<0.001)$. This indicated that the plant $\mathrm{EO}$ exerted more potent inhibitory effects on the MCF7 cells compared to the PC3 cells. However, in the case of paclitaxel, this difference was partly due to the very high cytotoxicity of paclitaxel to PC 3 cells $\left(\mathrm{IC}_{50}=0.09 \pm 0.03\right.$ compared to $3.45 \pm 0.39$ for the MCF7 cells).

Effects of the extract, different fractions and EO of Cyperus longus on cell apoptosis. The proportion of apoptotic cells was measured after PI staining of the DNA fragments using flow cytometry. The sub-G1 peak (one of the reliable biochemical markers of apoptosis) was observed at $48 \mathrm{~h}$ following treatment of the cells with the extract, the different fractions and the $\mathrm{EO}$ of Cyperus longus (Fig. 2). Our results indicated that the $\mathrm{EO}$ and the $\mathrm{CH}_{2} \mathrm{Cl}_{2}$ fraction at the same concentration $(75 \mu \mathrm{g} / \mathrm{ml})$ were the most effective inducers of apoptosis among the plant extracts examined in both the PC3 and MCF7 cancer cell lines (Table II). These data support the results obtained from MTT assay.

Chemical composition of EO. Hydro-distillation of the dried powder of the plant yielded a pale yellow-colored oil with a pleasant aroma, yield $0.45 \%(\mathrm{v} / \mathrm{w})$. A total of 32 components comprising $83.24 \%$ of the EO was identified (Table III). $\beta$-himachalene $(10.81 \%), \alpha$-caryophyllene oxide $(7.6 \%)$, irisone (4.78\%), $\beta$-caryophyllene oxide $(4.36 \%)$, humulene oxide (12\%), viridiflorol (4.73\%), aristolone (6.39\%) and longi- 
Cell line
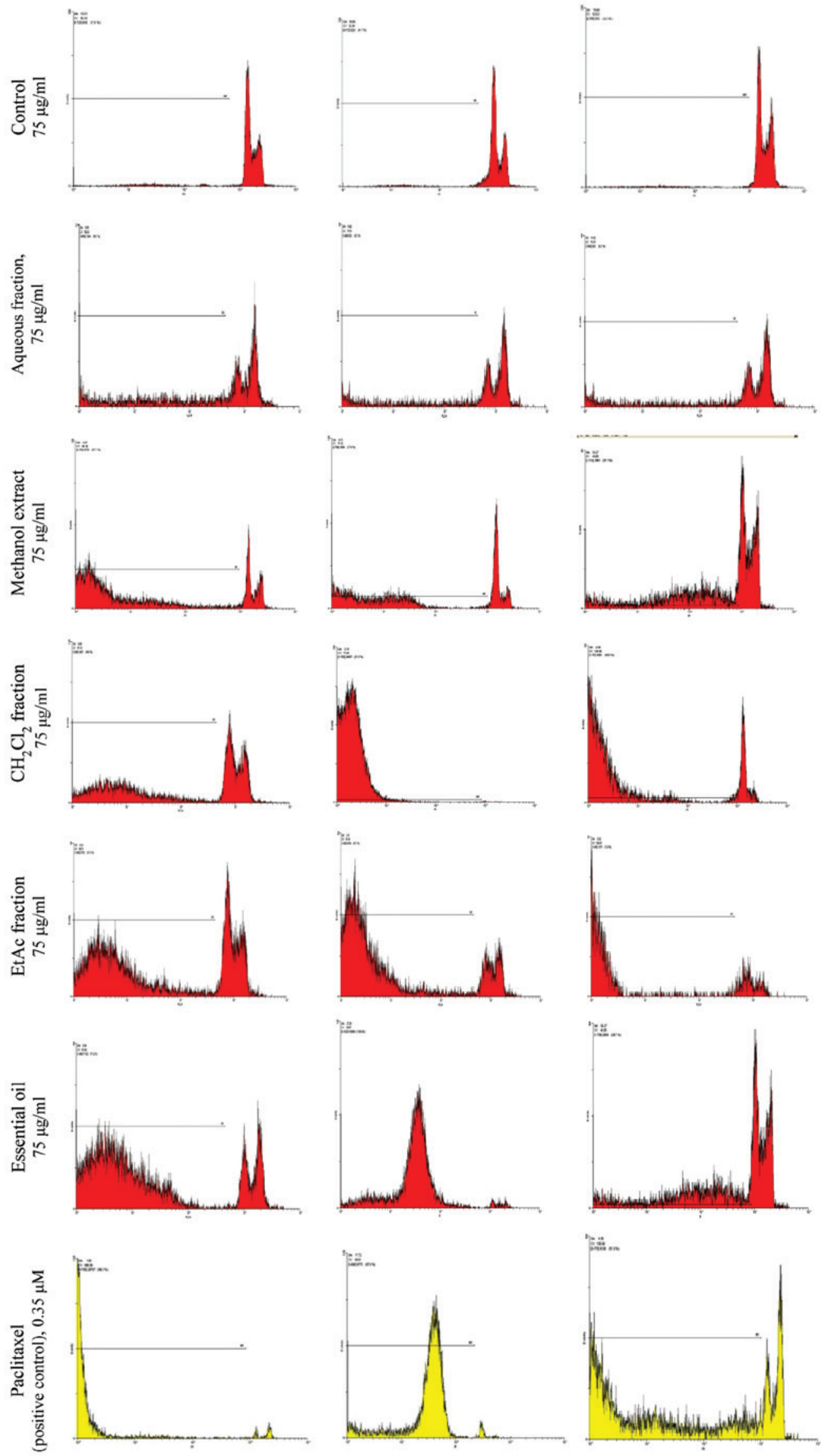

Figure 2. Flow cytometric analysis of the proportion of apoptotic cells. The proportion of apoptotic cells was measured after PI staining of the DNA fragments using flow cytometry. The sub-G1 peak (one of the reliable biochemical markers of apoptosis) was observed at $48 \mathrm{~h}$ following treatment of the cells with the extract, the different fractions and the $\mathrm{EO}$ of Cyperus longus. 
Table III. Chemical composition of the essential oil of Cyperus longus from North Khorasan, Iran.

\begin{tabular}{|c|c|c|c|c|}
\hline No. & Compound name & Area $\%$ & RI & Type of compound \\
\hline 1 & Linalool & 0.15 & $1,000.423$ & Monoterpene oxygenated \\
\hline 2 & cis-Dihydrocarvone & 0.22 & $1,100.42$ & Monoterpene oxygenated \\
\hline 3 & trans-Dihydrocarvone & 0.12 & $1,100.50$ & Monoterpene oxygenated \\
\hline 4 & $\alpha$-Cubebene & 0.23 & $1,200.90$ & Sesquiterpene \\
\hline 5 & $\alpha$-Copaene & 2.35 & $1,300.21$ & Sesquiterpene \\
\hline 6 & $\beta$-Elemene & 0.05 & $1,300.25$ & Sesquiterpene \\
\hline 7 & Germacrene-D & 0.61 & $1,300.33$ & Sesquiterpene \\
\hline 8 & Megastigmatrienone & 0.06 & $1,300.37$ & Monoterpene oxygenated \\
\hline 9 & $\alpha$-Gurjunene & 0.56 & $1,300.49$ & Sesquiterpene \\
\hline 10 & $\alpha$-Guaiene & 0.71 & $1,300.79$ & Sesquiterpene \\
\hline 11 & $\alpha$-Humulene & 1 & $1,300.99$ & Sesquiterpene \\
\hline 12 & $\alpha$-Amorphene & 1.16 & $1,400.18$ & Sesquiterpene \\
\hline 13 & Spathulenol & 0.97 & $1,400.41$ & Sesquiterpene oxygenated \\
\hline 14 & §-Guaiene & 1.27 & $1,400.48$ & Sesquiterpene \\
\hline 15 & Torreyol & 1.61 & $1,400.59$ & Sesquiterpene oxygenated \\
\hline 16 & 9-methyl-10-methylenetricyclo[4,2,1,1]decane-9-ol & 1.65 & $1,400.87$ & Monoterpene oxygenated \\
\hline 17 & $\beta$-Himachalene & 10.81 & $1,500.02$ & Sesquiterpene \\
\hline 18 & $\gamma$-Gurjunenepoxide & 1.4 & $1,500.11$ & Sesquiterpene oxygenated \\
\hline 19 & $\alpha$-Caryophyllene oxide & 7.6 & $1,500.22$ & Sesquiterpene oxygenated \\
\hline 20 & Irisone & 4.78 & $1,500.30$ & Monoterpene oxygenated \\
\hline 21 & $\beta$-Caryophyllene oxide & 4.36 & $1,500.35$ & Sesquiterpene oxygenated \\
\hline 22 & Humulene oxide & 12 & $1,500.65$ & Sesquiterpene oxygenated \\
\hline 23 & Retinol-acetate & 1.58 & $1,500.73$ & Diterpene oxygenated \\
\hline 24 & Limonene-1,2-epoxide & 2.15 & $1,500.80$ & Monoterpene oxygenated \\
\hline 25 & Viridiflorol & 4.73 & $1,600.02$ & Sesquiterpene oxygenated \\
\hline 26 & $\alpha$-Himachalene & 2.14 & $1,600.18$ & Sesquiterpene \\
\hline 27 & Longiverbenone & 6.04 & $1,600.29$ & Sesquiterpene oxygenated \\
\hline 28 & Aristolone & 6.39 & $1,600.57$ & Sesquiterpene oxygenated \\
\hline 29 & Cembrene & 1.71 & $1,600.67$ & Diterpene \\
\hline 30 & Viridiflorol & 0.79 & $1,600.75$ & Sesquiterpene oxygenated \\
\hline 31 & Aromadendrenepoxide & 1.1 & $1,600.92$ & Sesquiterpene oxygenated \\
\hline \multirow[t]{7}{*}{32} & 17-Acetoxy-19-kauranal & 3.1 & $1,800.64$ & Diterpene oxygenated \\
\hline & Total compounds & 83.24 & & \\
\hline & Monoterpene oxygenated & 9.13 & & \\
\hline & Sesquiterpene & 20.89 & & \\
\hline & Sesquiterpene oxygenated & 46.83 & & \\
\hline & Diterpene & 1.71 & & \\
\hline & Diterpene oxygenated & 4.68 & & \\
\hline
\end{tabular}

Retention index (RI) relative to the n-alkanes on the DB-5 MS capillary column. MS, identified on the basis of a comparison with MS data spectra.

verbenone $(6.04 \%)$ were identified as the major constituents of the EO. Among the identified components, 7 components comprising $9.13 \%$ of the EO were oxygenated monoterpenes, 11 components comprising $20.89 \%$ were sesquiterpene hydrocarbons, 11 components comprising $46.83 \%$ were oxygenated sesquiterpenes, 1 component comprising $1.71 \%$ was diterpene hydrocarbon and 2 components comprising $4.68 \%$ were oxygenated diterpenes.

\section{Discussion}

The data of the present study demonstrated that partially non-polar components from Cyperus longus exert more potent cytotoxic effects on the MCF7 than on the PC3 cells. The most effective fraction was the $\mathrm{CH}_{2} \mathrm{Cl}_{2}$ fraction followed by the EtOAc fraction and the methanol extract. The water (aqueous) fraction did not exhibit any significant anticancer activity in 
any cell lines $\left(\mathrm{IC}_{50}>100 \mu \mathrm{g} / \mathrm{ml}\right)$. All the effective fractions had more potent inhibitory effects on the MCF7 cells compared to the PC 3 cells. The critical time point for cytotoxic activity was $48 \mathrm{~h}$ following exposure; this indicated that there was a delay in reaching the maximum effect in both cell lines. The GC-MS data revealed that 32 components comprising $83.24 \%$ of the EO were identified (Table III). $\beta$-himachalene (10.81\%), $\alpha$-caryophyllene oxide (7.6\%), irisone (4.78\%), $\beta$-caryophyllene oxide $(4.36 \%)$, humulene oxide (12\%), viridiflorol (4.73\%), aristolone $(6.39 \%)$ and longiverbenone $(6.04 \%)$ were identified as the major constituents of the EO. As we already mentioned, $\beta$-himachalene (22), caryophyllene oxide (25) and $\alpha$-humulene $(20,21)$ have been shown to exert cytotoxic effects against cancer cell lines. The evaluation of the chemical composition of Cyperus longus EO from Morocco by the same method (GC-MS analysis) revealed a different spectrum of ingredients: $\alpha$-humulene (16.7\%), $\gamma$-himachalene (10.1\%) and $\beta$-himachalene (46.6\%) (31); however, as we have already mentioned, these agents also possess a satisfactory cytotoxic activity. Based on the percentage ratio of viridiflorol (4.73\%), aristolone (6.39\%), longiverbenone (6.04\%) and irisone (4.78\%) in our Cyperus longus EO, we searched the databases for the potential cytotoxicity of these two agents in PC3, MCF7 or other cell lines. It has been reported that longiverbenone isolated from the rhizome of Cyperus scariosus (45) exerts cytotoxic effects in newborn brine shrimp (Artemia salina) bioassay with a lethal concentration $\left(\mathrm{LC}_{50}\right)$ of $14.38 \mu \mathrm{g} / \mathrm{ml}$. These data support our results on the cytotoxic effects of Cyperus longus EO.

It has been reported in previous studies that aristolone does not exert cytotoxic effects against cancer cell lines, including human hepatocellular carcinoma (HepG2 and Hep3B), human breast carcinoma (MCF7 and MDA-MB-231) and human lung carcinoma (A-549) cells $(46,47)$. In a recent study, using MTT and lactate dehydrogenase (LDH) cytotoxic assays in human epithelial gastric cells (AGS cell line), viridiflorol fucoside, as a sesquiterpene glycoside from Calendula officinalis L., was shown to exert potent cytotoxic effects (48). Concerning irisone ( $\beta$-ionone), this agent was previously shown to exert toxic effects on the photosynthetic system of Microcystis aeruginosa NIES-843 (Cyanobacteria) with a half maximal effective concentration $\left(\mathrm{EC}_{50}\right)$ of $21.23 \pm 1.87 \mu \mathrm{g} / \mathrm{m}(49)$; however, to the very best of our knowledge, there is no availabe study to date on the cytotoxicity of this agent in cancer cell lines. Thus, further investigations are warranted to determine its exact cytotoxic effects on cancer cell lines.

In conclusion, in the present study, our findings demonstrated that the EO isolated from Cyperus longus exerts satisfactory cytotoxic effects on the PC3 and MCF7 cancer cell lines. Based on the chemical composition of the EO and since iridiflorol and longiverbenone belong to the constituents that make up at least $5 \%$ of the effective essential oil, it would be of interest to investigate the effects of viridiflorol and longiverbenone for their possible use as anticancer agents in the future.

\section{Acknowledgements}

This study was supported financially by a research grant from the Vice Chancellor for Research of North Khorasan University of Medical Sciences, Bojnurd, Iran.

\section{References}

1. Katzung BG, Masters SB and Trevor AJ (eds): Basic and Clinical Pharmacology. 12th edition. McGraw-Hill Companies, New York, NY, 2012.

2. Shao H, Jing K, Mahmoud E, Huang H, Fang X and Yu C: Apigenin sensitizes colon cancer cells to antitumor activity of ABT-263. Mol Cancer Ther 12: 2640-2650, 2013.

3. Xu H, Li X, Ding W, Zeng X, Kong H, Wang H and Xie W: Deguelin induces the apoptosis of lung cancer cells through regulating a ROS driven Akt pathway. Cancer Cell Int 15: 25, 2015.

4. Youssef Moustafa AM, Khodair AI and Saleh MA: Isolation, structural elucidation of flavonoid constituents from Leptadenia pyrotechnica and evaluation of their toxicity and antitumor activity. Pharm Biol 47: 539-552, 2009.

5. Seelinger G, Merfort I, Wölfle U and Schempp CM: Anti-carcinogenic effects of the flavonoid luteolin. Molecules 13: 2628-2651, 2008.

6. Samy RP, Gopalakrishnakone P and Ignacimuthu S: Anti-tumor promoting potential of luteolin against 7,12-dimethylbenz(a) anthracene-induced mammary tumors in rats. Chem Biol Interact 164: 1-14, 2006.

7. Lu J, Li G, He K, et al: Luteolin exerts a marked antitumor effect in cMet-overexpressing patient-derived tumor xenograft models of gastric cancer. J Transl Med 13: 42, 2015.

8. Zhang H, Zhang M, Yu L, Zhao Y, He N and Yang X: Antitumor activities of quercetin and quercetin-5',8-disulfonate in human colon and breast cancer cell lines. Food Chem Toxicol 50: 1589-1599, 2012

9. Wang P, Zhang K, Zhang Q, Mei J, Chen CJ, Feng ZZ and Yu DH: Effects of quercetin on the apoptosis of the human gastric carcinoma cells. Toxicol In Vitro 26: 221-228, 2012.

10. Borska S, Chmielewska M, Wysocka T, Drag-Zalesinska M, Zabel $\mathrm{M}$ and Dziegiel P: In vitro effect of quercetin on human gastric carcinoma: targeting cancer cells death and MDR. Food Chem Toxicol 50: 3375-3383, 2012.

11. Chan ST, Yang NC, Huang CS, Liao JW and Yeh SL: Quercetin enhances the antitumor activity of trichostatin A through upregulation of $\mathrm{p} 53$ protein expression in vitro and in vivo. PLOS One 8: e54255, 2013

12. Dixit S: Anticancer Effect of Rutin Isolated from the Methanolic Extract of Triticum aestivum Straw in Mice. Med Sci 2: 153-160, 2014.

13. Chen H, Miao Q, Geng M, Liu J, Hu Y, Tian L, Pan J and Yang Y: Anti-tumor effect of rutin on human neuroblastoma cell lines through inducing G2/M cell cycle arrest and promoting apoptosis. Scientific World Journal 29: 26915, 2013.

14. Al-Dhabi NA, Arasu MV, Park CH and Park SU: An up-to-date review of rutin and its biological and pharmacological activities. EXCLI J 14: 59-63, 2015.

15. Slavov A, Trifonov A, Peychev L, Dimitrova S, Peycheva S, Gotcheva V and Angelov A: Biologically active cCompounds with antitumor activity in propolis extracts from different geographic regions. Biotechnol Biotechnol Equip 27: 4010-4013, 2013.

16. Sahpazidou D, Geromichalos GD, Stagos D, Apostolou A, Haroutounian SA, Tsatsakis AM, Tzanakakis GN, Hayes AW and Kouretas D: Anticarcinogenic activity of polyphenolic extracts from grape stems against breast, colon, renal and thyroid cancer cells. Toxicol Lett 230: 218-224, 2014.

17. Henderson AJ, Ollila CA, Kumar A, Borresen EC, Raina K, Agarwal R and Ryan EP: Chemopreventive properties of dietary rice bran: current status and future prospects. Adv Nutr 3: 643-653, 2012.

18. Abbaszadeh H, Ebrahimi SA and Akhavan MM: Antiangiogenic activity of xanthomicrol and calycopterin, two polymethoxylated hydroxyflavones in both in vitro and ex vivo models. Phytother Res 28: 1661-1670, 2014.

19. Turkez H, Togar B, Tatar A, Geyıkoglu F and Hacimuftuoglu A: Cytotoxic and cytogenetic effects of $\alpha$-copaene on rat neuron and N2a neuroblastoma cell lines. Biologia 69: 936-942, 2014.

20. Costa EV, Menezes LR, Rocha SL, Baliza IR, Dias RB, Rocha CA, Soares MB and Bezerra DP: Antitumor properties of the leaf essential oil of Zornia brasiliensis. Planta Med 81: 563-567, 2015.

21. el Hadri A, del Río MAG, Sanz J, González-Coloma A, Idaomar M, Ozonas BR, González JB and Reus MIS: Cytotoxic activity of $\alpha$-humulene and transcaryophyllene from Salvia officinalis in animal and human tumor cells. An R Acad Nac Farm 76: 343-356, 2010. 
22. Saab AM, Guerrini A, Sacchetti G, Maietti S, Zeino M, Arend J, Gambari R, Bernardi F and Efferth T: Phytochemical analysis and cytotoxicity towards multidrug-resistant leukemia cells of essential oils derived from Lebanese medicinal plants. Planta Med 78: 1927-1931, 2012.

23. Babu HR and Savithramma N: Screening of secondary metabolites of underutilized species of Cyperaceae. Int J Pharm Sci Rev Res 24: 182-187, 2014.

24. Khamsan S, Liawruangrath B, Liawruangrath S Teerawutkulrag A, Pyne SG and Garson MJ: Antimalarial, anticancer, antimicrobial activities and chemical constituents of essential oil from the aerial parts of Cyperus kyllingia Endl. Rec Nat Prod 5: 324-327, 2011.

25. Legault J and Pichette A: Potentiating effect of $\beta$-caryophyllene on anticancer activity of $\alpha$-humulene, isocaryophyllene and paclitaxel. J Pharm Pharmacol 59: 1643-1647, 2007.

26. KumarKH,RazackS, NallamuthuI and KhanumF: Phytochemical analysis and biological properties of Cyperus rotundus L. Ind Crops Prod 52: 815-826, 2014.

27. Kilani-Jaziri S, Neffati A, Limem I, et al: Relationship correlation of antioxidant and antiproliferative capacity of Cyperus rotundus products towards K562 erythroleukemia cells. Chem Biol Interact 181: 85-94, 2009.

28. Kilani S, Ben Sghaier M, Limem I, Bouhlel I, Boubaker J, Bhouri W, Skandrani I, Neffatti A, Ben Ammar R, Dijoux-Franca MG, et al: In vitro evaluation of antibacterial, antioxidant, cytotoxic and apoptotic activities of the tubers infusion and extracts of Cyperus rotundus. Bioresour Technol 99: 9004-9008, 2008

29. Morikawa T, Xu F, Matsuda $\mathrm{H}$ and Yoshikawa M: Structures of novel norstilbene dimer, longusone $\mathrm{A}$, and three new stilbene dimers, longusols A, B, and C, with antiallergic and radical scavenging activities from Egyptian natural medicine Cyperus longus. Chem Pharm Bull (Tokyo) 58: 1379-1385, 2010.

30. Harborne J: Distribution and taxonomic significance of flavonoids in the leaves of the cyperaceae. Phytochemistry 10: $1569-1574,1971$

31. Ait-Ouazzou A, Lorán S, Arakrak A, Laglaoui A, Rota C, Herrera A, Pagán R and Conchello P: Evaluation of the chemical composition and antimicrobial activity of Mentha pulegium, Juniperus phoenicea, and Cyperus longus essential oils from Morocco. Food Res Int 45: 313-319, 2012.

32. Xu F, Morikawa T, Matsuda H, Ninomiya $\mathrm{K}$ and Yoshikawa $\mathrm{M}$ : Structures of new sesquiterpenes and hepatoprotective constituents from the Egyptian herbal medicine Cyperus longus. J Nat Prod 67: 569-576, 2004.

33. Sharma R and Gupta R: Cyperus rotundus extract inhibits acetylcholinesterase activity from animal and plants as well as inhibits germination and seedling growth in wheat and tomato. Life Sci 80: 2389-2392, 2007.

34. Ben-Arye E, Schiff E, Hassan E, Mutafoglu K, Lev-Ari S, Steiner M, Lavie O, Polliack A, Silbermann M and Lev E: Integrative oncology in the Middle East: from traditional herbal knowledge to contemporary cancer care. Ann Oncol 23: 211-221, 2012.

35. Shao H, Jing K, Mahmoud E, Huang H, Fang X and Yu C: Apigenin sensitizes colon cancer cells to antitumor activity of ABT-263. Mol Cancer Ther 12: 2640-2650, 2013.
36. Apostolou A, Stagos D, Galitsiou E, Spyrou A, Haroutounian S, Portesis N, Trizoglou I, Wallace Hayes A, Tsatsakis AM and Kouretas D: Assessment of polyphenolic content, antioxidant activity, protection against ROS-induced DNA damage and anticancer activity of Vitis vinifera stem extracts. Food Chem Toxicol 61: 60-68, 2013.

37. Androutsopoulos VP, Ruparelia KC, Papakyriakou A, Filippakis H, Tsatsakis AM and Spandidos DA: Anticancer effects of the metabolic products of the resveratrol analogue, DMU-212: Structural requirements for potency. Eur J Med Chem 46: 2586-2595, 2011.

38. Xue YQ, Di JM, Luo Y, Cheng KJ, Wei X and Shi Z: Resveratrol oligomers for the prevention and treatment of cancers. Oxid Med Cell Longev 2014: 765832, 2014.

39. Parsaee H, Asili J, Mousavi SH, Soofi H, Emami SA and Tayarani-Najaran Z: Apoptosis Induction of Salvia chorassanica Root Extract on Human Cervical Cancer Cell Line. Iran J Pharm Res 12: 75-83, 2013.

40. Diao WR, Hu QP, Zhang H and Xu JG: Chemical composition, antibacterial activity and mechanism of action of essential oil from seeds of fennel (Foeniculum vulgare Mill.). Food Contr 35: 109-116, 2014.

41. Malaekeh-Nikouei B, Mousavi SH, Shahsavand S, Mehri S, Nassirli $\mathrm{H}$ and Moallem SA: Assessment of cytotoxic properties of safranal and nanoliposomal safranal in various cancer cell lines. Phytother Res 27: 1868-1873, 2013.

42. Mousavi SH, Moallem SA, Mehri S, Shahsavand S, Nassirli H and Malaekeh-Nikouei B: Improvement of cytotoxic and apoptogenic properties of crocin in cancer cell lines by its nanoliposomal form. Pharm Biol 49: 1039-1045, 2011.

43. Olaru OT, Venables L, VAN DE Venter M, Nitulescu GM, Margina D, Spandidos DA and Tsatsakis AM: Anticancer potential of selected Fallopia Adans species. Oncol Lett 10: 1323-1332, 2015

44. Boussaada O, Ammar S, Saidana D, Chriaa J, Chraif I, Daami M, Helal AN and Mighri Z: Chemical composition and antimicrobial activity of volatile components from capitula and aerial parts of Rhaponticum acaule DC growing wild in Tunisia. Microbiol Res 163: 87-95, 2008.

45. Rahman MS and Anwar MN: Antibacterial and Cytotoxic Activity of Longiverbenone Isolated from the Rhizome of Cyperus scariosu. Bangladesh J Microbiol 25: 82-84, 2008.

46. Su JH, Dai CF, Huang $\mathrm{HH}, \mathrm{Wu}$ YC, Sung PJ, Hsu CH and Sheu JH: Terpenoid-related metabolites from a formosan soft coral Nephthea chabrolii. Chem Pharm Bull (Tokyo) 55: 594-597, 2007

47. Kamada T and Vairappan CS: New bioactive secondary metabolites from Bornean red alga, Laurencia similis (Ceramiales). Nat Prod Commun 8: 287-288, 2013.

48. D'Ambrosio M, Ciocarlan A, Colombo E, Guerriero A, Pizza C, Sangiovanni E and Dell'Agli M: Structure and cytotoxic activity of sesquiterpene glycoside esters from Calendula officinalis L: Studies on the conformation of viridiflorol. Phytochemistry 117: $1-9,2015$

49. Shao J, Xu Y, Wang Z, Jiang Y, Yu G, Peng X and Li R: Elucidating the toxicity targets of $\beta$-ionone on photosynthetic system of Microcystis aeruginosa NIES-843 (Cyanobacteria). Aquat Toxicol 104: 48-55, 2011. 